\title{
PERANCANGAN APLIKASI QUESTION ANSWERING SYSTEM PADA TERJEMAHAN ALQURAN
}

\author{
Arfiani Nur Khusna ${ }^{1)}$, Murein Miksa Mardhia ${ }^{2)}$ \\ 1,2) Teknik Informatika Universitas Ahmad Dahlan \\ email : arfiani.khusna@tif.uad.ac.id ${ }^{l}$, murein.miksa@tif.uad.ac.id ${ }^{2}$
}

\begin{abstract}
Abstraksi
Al quran merupakan tuntunan bagi umat Islam. Suatu permasalahan tidak hanya mengacu pada satu ayat ataupun satu surat sehingga dibutuhkan waktu yang lama dalam proses pencarian secara manual, mengingat banyaknya jumlah ayat dan surat yang terkandung dalam Al quran. Berdasarkan hasil kuisioner yang dibagikan kepada 50 responden, terdapat $75 \%$ responden tidak dapat atau kesulitan dalam mencari jawaban terhadap makna atau masalah yang didasarkan pada terjemahan Al quran. Question answering system adalah sistem yang mengijinkan user menyatakan kebutuhan informasinya dalam bentuk natural language question (pertanyaan dalam bahasa alami), dan mengembalikan kutipan teks singkat atau bahkan frase sebagai jawaban. Penelitian ini merancang aplikasi question answering system pada terjemahan al quran untuk membantu pengguna menemukan jawaban terjemahan Al quran dengan menggunakan pertanyaan yaitu dimana, apa, siapa, berapa, kapan dan mengapa. Berdasarkan hasil pengujian rancangan aplikasi diperoleh nilai usability 28 dari 35 yang menunjukkan bahwa rancangan aplikasi layak dikembangkan sebagai alat bantu dalam mencari jawaban terjemahan Al quran dan sesuai kebutuhan pengguna.
\end{abstract}

Kata Kunci :

question answering system, terjemahan al quran, rancangan aplikasi

\section{Pendahuluan}

Al quran sebagai pedoman utama umat Islam berisi firman-firman Allah dan diturunkan dalam bahasa Arab, namun agama Islam tak hanya di Jazirah Arab, agama Islam berkembang hingga ke seantero dunia. Al quran sebagai kitab suci tidak hanya wajib dibaca, namun juga dikaji, dipahami, dan diamalkan. Salah satu cara untuk memudahkan umat Islam dalam memahami isi Al quran yaitu menterjemahkan ke dalam berbagai bahasa, termasuk bahasa Indonesia.

Pada proses pencarian makna atau sebuah permasalahan pada Al quran tidaklah mudah, dikarenakan dalam Al quran suatu makna atau permasalahan tidak mengacu pada satu surat atau satu ayat sehingga dibutuhkan waktu yang lama dalam proses pencarian secara manual, mengingat banyaknya jumlah ayat dan surat yang terkandung dalam Al quran. Dari hasil kuisioner yang disebarkan kepada 50 responden, terdapat $75 \%$ responden yang kesulitan dalam mencari jawaban dari pencarian makna atau masalah yang mengacu dalam Al quran.

Question Answering (QA) System merupakan kajian dengan konsep pengguna memasukkan sebuah query berupa pertanyaan dan sistem akan memberikan umpan balik berupa jawaban dari pertanyaan yang diajukan oleh pengguna secara langsung sehingga mempercepat proses penemuan masalah. QA System dapat dimanfaatkan dalam menyebarkan informasi pada berbagai aspek kehidupan tak terkecuali informasi pada aspek agama [1].

QA System merupakan sebuah sistem yang mengijinkan pengguna untuk menanyakan dalam bentuk yang lebih spesifik dan alami, yaitu dalam bentuk pertanyaan bahasa alami (natural language question), dan pengguna harus menyaring untuk menentukan apakah dokumen-dokumen tersebut mengandung jawaban atas pertanyaan, QA System mengembalikan kutipan teks singkat atau frase sebagai jawaban [2]

QA System didasarkan pada komponen inti yaitu: analisa pertanyaan (question analysis) meliputi komponen analisa pertanyaan berasal dari informasi sintaksis atau semantik dari pertanyaan, pembentukan query (query generation) yaitu informasi diubah menjadi sebuah set query pencarian yang akan diteruskan ke komponen pencarian untuk menemu kembalikan konten yang relevan dari kumpulan sumber pengetahuan, hasil pencarian akan diproses oleh candidate generation yang mengekstrak kandidat dari jawaban, pada tahapan pembentukan kandidat jawaban dan penilaian jawaban (candidate answer generation and answer scoring) akan memperkirakan nilai kepercayaan dari kandidat jawaban, kemudian merangkingnya, dan menggabungkan kandidat jawaban yang sama. [2]

Terdapat beberapa tipe QA berdasarkan jawaban yang dihasilkannya. Tipe pertanyaan yang ditangani sebuah QA system terbagi atas 5 jenis pertanyaan yaitu factoid, non-factoid, yes no, list, dan opini. 
Untuk domain Bahasa Indonesia, sistem QA yang sudah ada hanya menangani pertanyaan factoid yaitu pertanyaan yang jawabannya berupa frase singkat dari orang, lokasi, organisasi, tanggal, angka, dan jenis jawaban singkat lainnya [3]. Dalam membangun QA system dengan pendekatan pola bahasa Indonesia, terdapat membangun pola pertanyaan yang terdiri dari tipe pertanyaan yaitu orang, waktu, tempat, organisasi, ukuran, angka, dll [4].

QA system mempunyai masalah pada ketidakakuratan karena beberapa faktor. Pertama, pertanyaan yang diberikan terlalu umum atau terlalu khusus sehingga kalimat benar, tidak berhasil terambil. Pada paragraf yang mengandung jawaban memiliki kata kunci yang tersebar pada beberapa kalimat dari paragraf tersebut sehingga nilai kalimat menjadi lebih rendah dibanding kalimat lain yang memiliki kata kunci yang lebih banyak dan terdapat kalimat salah yang mengandung pola jawaban benar dan nilai kata kunci yang tinggi [5].

Pada penelitian ini aplikasi dirancang dengan pola pertanyaan berdasarkan tipe pertanyaan yaitu kata tanya utama merupakan indikasi dari masing-masing tipe pertanyaan dan posisi kata kunci dari pertanyaan dalam sebuah kalimat tanya menunjukkan konteks dan target dari pertanyaan. Pertanyaan yang digunakan yaitu dimana, apa, siapa, berapa, kapan dan mengapa.

Penggunaan analisa usability digunakan untuk penentuan tingkat kemudahan pengguna menggunakan rancangan antarmuka aplikasi dan mengevaluasi apakah aplikasi telah sesuai dengan kebutuhan pengguna, jika fungsi aplikasi dapat dijalankan secara efektif dan memuaskan maka disebut usable [6].

Pengujian usability merupakan analisa kualitatif yang menentukan seberapa mudah user menggunakan antarmuka suatu aplikasi [7]. Keberhasilan pengguna mencapai tujuan berhubungan dengan efektifitas dalam menggunakan suatu perangkat lunak. Efisiensi berkenaan dengan kelancaran pengguna untuk mencapai tujuan tersebut. Suatu aplikasi disebut usable jika fungsifungsinya dapat dijalankan secara efektif, efisien, dan memuaskan [7]. Kepuasan berkaitan dengan sikap penerimaan pengguna terhadap perangkat lunak. Pengujian usability dilakukan untuk mengevaluasi apakah sebuah aplikasi sudah sesuai dengan kebutuhan pengguna atau belum.

\section{Metode Penelitian}

Tahapan penelitian terdapat pada gambar 1, meliputi:

1. Analisa data dan informasi pada rancangan aplikasi yang akan dikembangkan.

2. Analisa kebutuhan aplikasi yang terdiri dari use case diagram dan rancangan struktur navigasi aplikasi.
3. Hasil perancangan aplikasi berdasarkan analisa data dan informasi yang dihasilkan.

4. Pengujian usability untuk menguji kelayakan dari rancangan aplikasi sebelum pengembangan aplikasi.

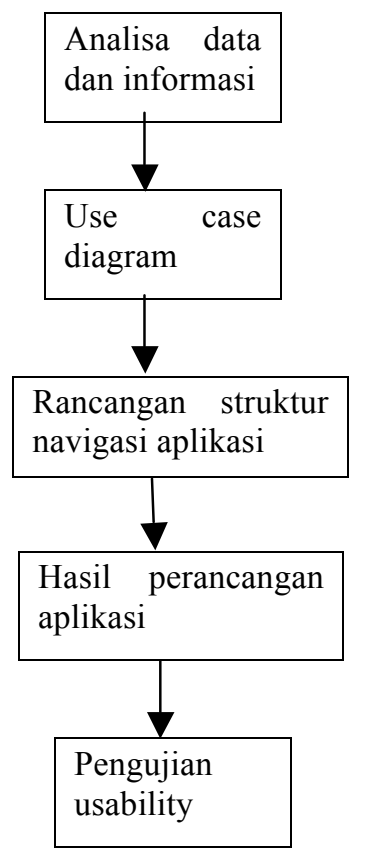

Gambar 1. Tahapan Penelitian

\section{Hasil dan Pembahasan}

\section{A. Hasil Analisa}

Analisa data pada rancangan aplikasi yang akan dikembangkan berdasarkan hasil pengumpulan data dengan metode literatur dan wawancara.

1. Analisa kebutuhan data dan informasi meliputi

a. Pengguna aplikasi meliputi admin dan pengguna umum.

b. Data kata tanya berisi data kata tanya yang akan digunakan.

c. Stoplist berisi data kata yang tidak berpengaruh atau tidak memiliki arti dari pertanyaan maupun jawaban.

d. Kata dasar berisi bentuk kata dasar dan tipe kata dasar.

e. Terjemahan Al quran mencakup dokumen, teks bahasa arab dan terjemahan.

f. Indeks berisi data hasil indeks dokumen.

g. Bobot berisi data hasil pembobotan dokumen.

h. Kemiripan berisi data dokumen yang mempunyai kemiripan dengan query.

i. Jumlah keyword berisi jumlah keyword kalimat yang menjadi kandidiat jawaban. 
j. Answer type berisi data kalimat yang menjadi kandidat jawaban dari answer type filter.

k. Kamus jawaban berisi jawaban yang terdapat dalam terjemahan Al quran

1. Pola jawaban berisi data pola jawaban untuk mengekstrak property jawaban.

2. Analisa kebutuhan aplikasi

a. Use case diagram analisa aplikasi

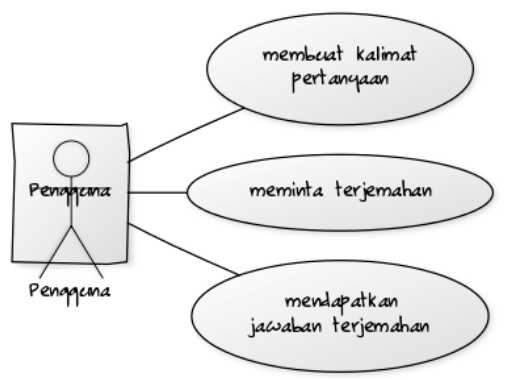

Gambar 2. Use case diagram pengguna

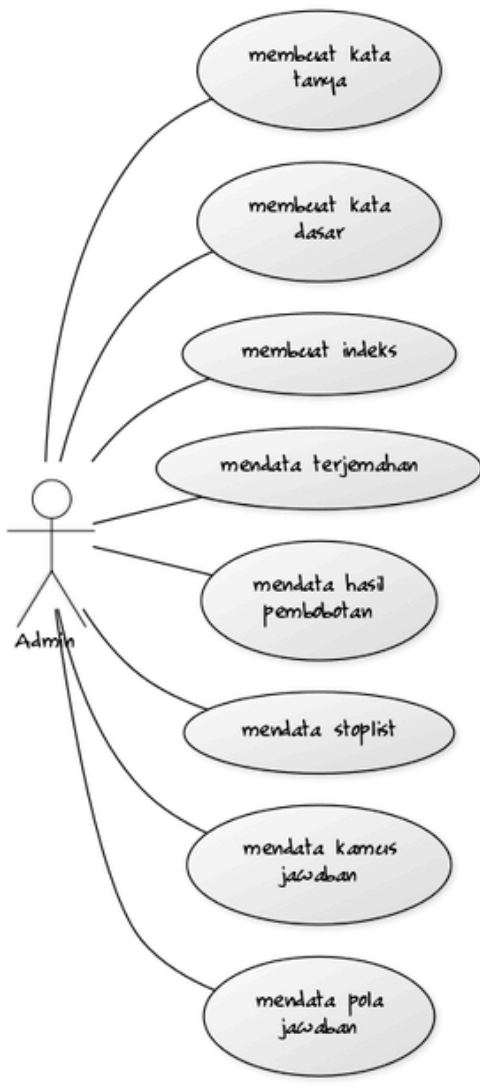

Gambar 3. Use case diagram admin

Use case diagram pada gambar 2 memiliki 3 aktivitas yaitu:

a. Pengguna dapat membuat kalimat pertanyaan dengan memilih kata tanya berupa dimana, apa, siapa, berapa, kapan dan mengapa.

b. Pengguna dapat meminta terjemahan dari kalimat pertanyaan yang diajukan dan pengguna mendapatkan terjemahan.
Use case diagram pada gambar 3 terdapat 8 aktivitas yaitu:

a. Membuat kata tanya berupa dimana, apa, siapa, berapa, kapan dan mengapa.

b. Membuat kamus kata dasar bahasa Indonesia.

c. Membuat perhitungan indeks

d. Membuat kamus terjemahan

e. Membuat perhitungan hasil pembobotan

f. Membuat kata stoplist

g. Membuat kamus jawaban

h. Merumuskan pola jawaban.

b. Rancangan struktur navigasi

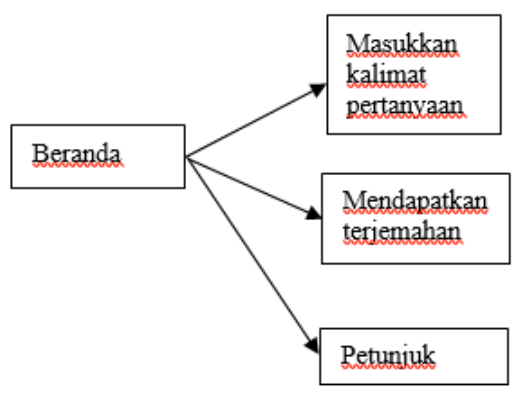

Gambar 4. Rancangan struktur navigasi pengguna

Gambar 4 merupakan struktur navigasi bagian pengguna yang akan diimplementasikan pada aplikasi yang akan dikembangkan.

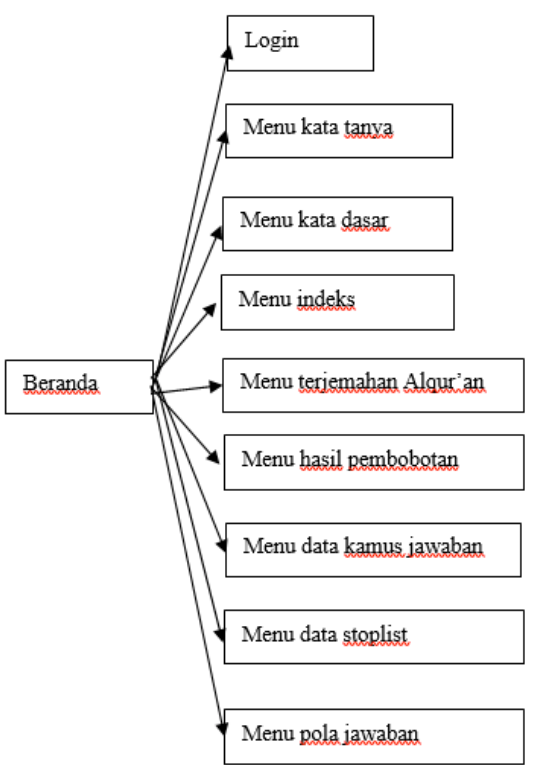

Gambar 5. Rancangan struktur navigasi admin

Gambar 5 merupakan struktur navigasi bagian admin yang akan diimplementasikan pada aplikasi yang akan dikembangkan.

B. Hasil perancangan aplikasi 
Hasil perancangan antar muka aplikasi berdasarkan aktivitas pengguna yang telah dihasilkan, seperti pada gambar 6 terdapat icon login untuk admin, icon Semua terjemahan untuk melihat semua terjemahan Al quran, icon petunjuk untuk melihat cara menggunakan aplikasi, icon masukkan pertanyaan untuk memasukkan pertanyaan yang dikehendaki pengguna dengan kata tanya dimana, apa, siapa, berapa, kapan dan mengapa, icon tanya untuk klik setelah memasukkan pertanyaan dan icon jawaban untuk menampilkan jawaban.

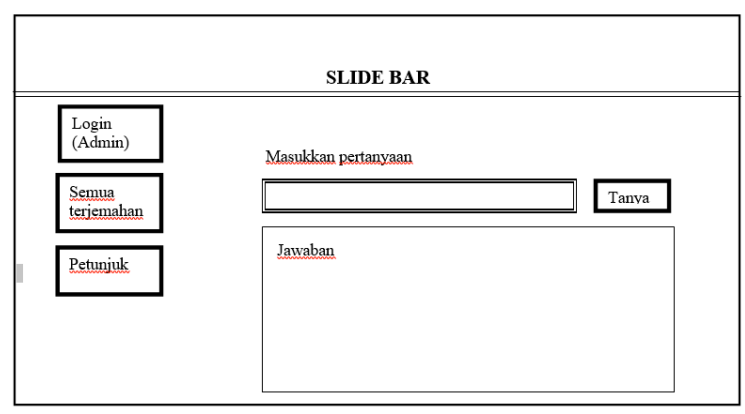

Gambar 6. Rancangan antar muka pengguna Pada aplikasi ini terdapat halaman khusus untuk admin yang bertujuan untuk mengelola pengetahuan sistem berdasarkan metode question answering system, untuk mengakses halaman admin maka harus terlebih dahulu melakukan login, rancangan antar muka login admin terdapat gambar 7.

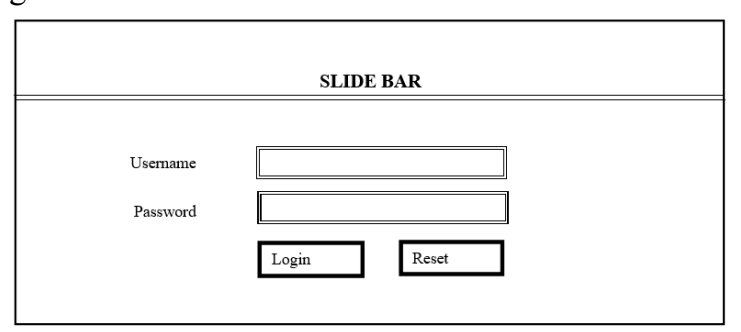

Gambar 7. Rancangan antar muka login admin

Antar muka yang akan digunakan admin dalam mengakses menu pada aplikasi terdapat pada gambar 8, yang terdiri icon beranda untuk kembali ke halaman awal, icon menu yang akan mendetailkan setiap tahap question answering system, icon logout untuk keluar sistem.

\begin{tabular}{|c|c|}
\hline & SLIDE BAR \\
\hline Beranda & \\
\hline Menu & \\
\hline Logout & \\
\hline
\end{tabular}

Gambar 8. Rancangan antar muka admin

\section{Pengujian Usability}

Pengujian usability dilakukan untuk menguji kelayakan dari rancangan sebelum dilakukan pengembangan aplikasi. Uji kelayakan berdasarkan dengan kesesuain kebutuhan pengguna. Mengukur kelayakan menggunakan lembar kuisioner berupa pertanyaan yang sesuai berdasarkan kuisioner sebelum dibuatnya rancangan aplikasi. Kuesioner menggunakan 7 pertanyaan yang disebarkan kepada 50 responden. Pertanyaan terdiri dari apakah rancangan aplikasi sesuai dengan keinginan pengguna, apakah alur aplikasi sesuai dengan kebutuhan pengguna, apakah permintaan input pertanyaan dapat dipahami, apakah alur aplikasi mudah dipahami, apakah rancangan aplikasi akan membantu menampilkan terjemahan, apakah rancangan sistem membuat kesulitan untuk mencari terjemahan, apakah fitur-fitur pada rancangan mudah dipahami. Setiap pertanyaan bernilai satu hingga lima, satu merupakan sangat tidak setuju hingga lima merupakan sangat setuju. Hasil ratarata yang didapat dari kuesioner adalah 32, dengan nilai maksimal 35. Hasil kuisioner menunjukkan rancangan aplikasi sesuai dengan kebutuhan pengguna.

\section{Kesimpulan dan Saran}

Rancangan pada pengembangan aplikasi dapat memasukkan pertanyaan pengguna dengan kata tanya dimana, apa, siapa, berapa, kapan dan mengapa, rancangan aplikasi juga dapat menampilkan jawaban dari pertanyaan pengguna serta menampilkan semua terjemahan Al quran. Dari hasil perolehan pengujian usability menunjukkan bahwa rancangan aplikasi question answering system pada terjemahan Al quran ini layak untuk dikembangkan karena aplikasi sesuai dengan kebutuhan pengguna dan dapat diterima sebagai aplikasi yang membantu menjawab pertanyaan dan makna dari terjemahan Al quran. Hal ini dilakukan sebagai kunci keberhasilan agar aplikasi bisa dikembangkan, diterima dan bermanfaat bagi masyarakat.

\section{Daftar Pustaka}

[1] Rosiana L. C, "Question Answering Sistem pada Terjemah Juz Amma Menggunakan Metode Rule Based." Tugas Akhir Fakultas Sains dan Teknologi, UIN Maulana Malik Ibrahim, 2012.

[2] Suzan Verberne et.al, "Learning to rank for whyquestion answering." Information Retrieval, vol.14 no.2, p.107-132, 2011

[3] A. Purwarianti, "Developing Cross Language Systems for Language Pair with Limited Resource: Indonesian - Japanese CLIR and CLQA, Ph.D Thesis." Toyohashi University of Technology, Japan, 2007.

[4] Sapitri A.I, Al-Faraby S, Adiwijaya. "Analisis Metode Pattern Based Approach Question Answering System Pada Dataset Hukum Islam Berbasis Bahasa Indonesia.” Media Informatika Budidarma, vol. 2 no. 4, p. 159-164, 2018. 
[5] Y. Nurhadryani, S. K. Sianturi, and I. Hermadi, "Pengujian Usability untuk Meningkatkan Antarmuka Aplikasi Mobile Usability Testing to Enhance Mobile Application User Interface.” Ilmu Komput. Agri-Informatika, vol. 2, p. 83-93, 2013.

[6] Khusna A N, Rizkawati L, "Perancangan Sistem Informasi Panduan Gizi Makanan Balita." Seminar Nasional Informatika Medis (SNIMed), 3-8, 2018.

[7] Nielsen J. "Usability Engineering." San Francisco: Morgan Kaufmann, 1993. 